\title{
MUCTEUTBOBHA BCTBO
}

УДК 78.03+78.087 (784.5)

DOI https://doi.org/10.24919/2308-4863/39-2-1

\author{
Юрій КУЧУРІВСЬКИЙ, \\ orcid.org/0000-0003-0007-8636 \\ кандидат мистеитвознавства, \\ стариий викладач кафедри хорового диригування \\ Одеської начіональної музичної академії імені А. В. Нежданової \\ (Одеса, Україна) yskuchurivskyy@ukr.net
}

\section{РЕКВІЄМИ Ф. ДЕЛІУСА І ДЖ. ФОУЛДА В КУЛЬТУРНО-ІСТОРИЧНОМУ КОНТЕКСТІ АНГЛІЙСЬКОГО МУЗИЧНОГО МИСТЕЦТВА ХХ СТОЛІТТЯ}

У статті розглядаються хорові реквієми видатних представників англійської композиторської школи ХХ століття Ф. Деліуса і Дж. Фоулда в широкому культурно-історичному контексті. Зазначено, щьо жанр реквієму склав пріоритетний напрямок хорової творчості британських композиторів у ХХ столітті та відобразив специфічні особливості індивідуально-композиторських інтерпретацій жанрового канону провідного меморіального жанру європейської музичної традиції. Розглянуто витоки й особливості композиторського задуму Реквіємів вказаних композиторів у їхніх взаємозв'язках із воєнною тематикою.

Мета статті полягає у виявленні характерних особливостей хорових Реквіємів Ф. Деліуса $і$ Дж. Фоулда в культурно-історичному контексті англійського музичного мистецтва ХХ століття.

Доведено, щз інтерес англійських композиторів до жанру заупокійної меси зумовлений історичними подіями; він став особистою відповіддю майстрів музичного мистеиттва на трагедію Першої світової війни, яка збіглася з англійським музичним Відродженням кіния XIX - початку XX століть як стимулюючим фактором розвитку меморіального жанру реквієму.

Виявлено, щзо хорові реквієми Ф. Деліуса і Дж. Фоулда виступають оригінальними зразками творчої композиторської інтерпретації жанрового канону реквієму, зумовленими національно-культурними особливостями англійської музичної традииї і ї̈ історичним контекстом сучасності. Зазначено, щзо особливе значення для композиторських кониепиій реквіємів Ф. Деліуса і Дж. Фоулда має приниип синтезу, щчо відображено в об'єднанні різноманітних літературно-поетичних джерел і музично-стильових моделей. У Реквіємах Ф. Деліуса $і$ Дж. Фоулда виявляється тенденція до трансформації вихідної меморіально-заступницької функиї богослужбового жанру в ідею загальності (незалежно від конфесійної приналежності), загальної пам'яті про всіх, хто загинув у світовій війні. Зазначений ідейний зміст хорових реквіємів англійських композиторів вплинув на трансформацію образно-семантичного інваріанта заупокійної меси. Мова йде про принципове розширення змістовно-смислових меж «меси мертвих», в якій композитори об'єднують культурні традииї Заходу й Сходу за допомогою використання синтезу літературно-поетичних текстів - канонічних текстів латинського реквієму, мусульманської та індуїстської релігійної і поетичної традицій.

Ключові слова: реквієм; хорове мистецтво; англійська музика; англійський ренесанс; композитор; меморіальний жанр; воєнна тема.

Yurii KUCHURIVSKY, orcid.org/0000-0003-0007-8636

Candidate of Art History,

Senior Lecturer at the Department of the Choral Conducting Odesa National A. V. Nezhdanova Academy of Music (Odessa, Ukraine) yskuchurivskyy@ukr.net

\section{REQUIEMS OF F. DELIUS AND J. FOULDS IN THE CULTURAL AND HISTORICAL CONTEXT OF ENGLISH MUSIC ART OF THE XX CENTURY}

The article examines the choral requiems of prominent representatives of the English composition school of the twentieth century F. Delius and J. Foulds in a broad cultural and historical context. It is noted that the requiem genre was a priority of choral work of British composers in the twentieth century, which reflected the specific features of individualcomposer interpretations of the genre canon of the leading memorial genre of the European musical tradition. The origins and peculiarities of the compositional plan of the Requiems of the mentioned composers in their interrelations with military themes are considered. 
The purpose of the article is to identify the characteristics of the choral requiems of F. Delius and J. Foulds in the cultural and historical context of English musical art of the twentieth century.

It is proved that the interest of English composers in the genre of funeral mass was due to historical events, it was a personal response of masters of music to the tragedy of World War I, which coincided with the English musical Renaissance of the late nineteenth - early twentieth centuries as a stimulating factor.

It was found that the choral requiems of F. Delius and J. Foulds are original examples of creative compositional interpretation of the genre canon of the requiem, which were due to national and cultural features of the English musical tradition and its historical context. It is noted that the principle of synthesis, which is reflected in the combination of various literary and poetic sources and musical and stylistic models, is of special importance for the compositional concepts of the requiems of F. Delius and J. Foulds. In the Requiems of F. Delius and J. Foulds there is a tendency to transform the original memorial-patron function of the liturgical genre into the idea of universality (regardless of religious affiliation), the common memory of all those who died in World War. This ideological content of the choral requiems of English composers influenced the transformation of the figurative-semantic invariant of the funeral mass: it is a matter of fundamentally expanding the semantic boundaries of the "mass of the Dead", in which composers combine cultural traditions of West and East - canonical texts of the Latin Requiem, Muslim and Hindu religious and poetic traditions.

Key words: requiem, choral art, English music, English renaissance, composer, memorial genre, military theme.

Постановка проблеми. В історії англійської хорової музики жанр реквієму посідає визначне місце. Він склав пріоритетний напрямок композиторської творчості XX століття та втілив характерні особливості розвитку провідного меморіального жанру європейської музичної традиції у музичній культурі Великої Британії. Реквієми Ф. Деліуса і Дж. Фоулда, що є видатними зразками хорової творчості англійських композиторів минулого століття, міцно закріпилися в світовій виконавській практиці, однак для вітчизняної музичної культури вони маловідомі, хоча інтерес до британського хорового мистецтва в останні десятиліття все частіше виявляється в сучасному українському виконавстві. Ця ситуація вимагає дослідницької уваги до маловідомих в Україні творів англійських композиторів, що дозволить виявити їхнє місце в еволюції європейської традиції хорового мистецтва, національнустильову специфіку індивідуально-композиторських інтерпретацій жанрового канону реквієму й особливості взаємодії із провідними жанровостильовими тенденціями музичного мистецтва $\mathrm{XX}$ століття. 3 огляду на те, що ця проблематика досі не ставала спеціальним предметом музикознавчих досліджень і враховуючи активну інтеграцію українського хорового мистецтва в європейський музично-виконавський контекст, потреба теоретичного освоєння Реквіємів Ф. Деліуса та Дж. Фоулда як репрезентантів англійського хорового мистецтва, які посіли міцних позицій у сучасному хоровому репертуарі, не викликає сумніву. Актуальність звернення до цієї теми очевидна.

Аналіз досліджень і публікацій. Нині спеціальними дослідженнями в галузі англійської хорової культури є роботи Л. Г. Ковнацької, яка досі вважається найбільш авторитетним фахівцем у сфері музичної культури Англії: відомості про загальну історію англійської хорової музики та окремі твори композиторів XX століття містяться в іiі монографії (Ковнацька, 1986) та окремих статтях. Англомовні джерела, в яких містяться розрізнені відомості з історії жанру реквієму в англійській професійній музиці та індивідуально-композиторського трактування цього жанру, представлені дослідженнями С. Коваленко (Kovalenko, 1971), М. X'юса і Р. Стредлінга (Hughes, Stradling, 2001), M. Тренда (Trend, 1985) та інших. Історичний контекст становлення професійного англійського хорового мистецтва та його літургійних витоків висвітлений у фундаментальній праці Е. ВілсонаДіксона «Історія християнської музики» (Уилсон-Диксон, 2001). Історична доля заупокійної меси не обговорюється цим автором у контексті основних принципів реформування богослужбової практики в англіканській церкві, якій автор дослідження приділяє значну увагу. Відповідно, в книзі не зачіпаються і реквієми англійських композиторів XX століття, залишаючи відкритим питання про причини такого живого інтересу представників національної хорової традиції до цього жанру. Проблемі розвитку жанру реквієму в творчості британських композиторів другої половини XX століття присвячене дисертаційне дослідження автора цієї статі (Кучурівський, 2019).

Мета статті - виявити характерні особливості хорових Реквіємів Ф. Деліуса і Дж. Фоулда в культурно-історичному контексті англійського музичного мистецтва XX століття.

Виклад основного матеріалу. В історії музичного мистецтва Великої Британії початок $\mathrm{XX}$ століття є особливим і вкрай важливим періодом, 3 яким пов'язано оновлення національнокультурних традицій i посилення активності композиторської творчості, що знайшло відображення у відомому визначенні англійського музичного Відродження. Англійський музичний ренесанс набирав обертів, коли Перша світова 
війна почала прориватися Європою. Перетин обох історичних подій значно вплинув на долю жанру реквієму, який мав усі підстави зазнати свого динамічного розвитку в творчості композиторів Англії. Авторські задуми багатьох композиторів породжені відповідно до провідних етичних проблем свого часу, що пов'язано з художнім осмисленням нагальних питань людського життя. Серед цих питань мілітаризм займав центральне місце, оскільки неминуче був пов'язаний з онтологічними питаннями цінності людського життя в сучасному суспільстві. Військові конфлікти як «ознака епохи» природним чином знаходять відгук у сфері художньої творчості. В музичному мистецтві ця проблема часто інтерпретується 3 позицій фіксації «пам'яті про загиблих» і заповіту цієї пам'яті наступним поколінням. Унаслідок цього затребуваним в композиторській практиці початку XX століття виявляється жанр реквієму, меморіальна функція якого в повній мірі відповідає художнім прагненням композиторів.

Видатними зразками англійського хорового реквієму першої половини XX століття виступають Реквісм Фредеріка Деліуса (1916), Світовий реквієм Джона Фоулда (1919-21), Камерний Реквієм Джеральда Фінці (1923), Реквієм Архангелів для світу Джуліуса Гаррісона (1920), Короткий реквієм Уолфорда Девіса (1915) і Реквієм Герберта Хауелла (1932). Перелічені твори слід розглядати в якості безпосередньої реакції англійських композиторів на трагедію Першої світової війни, як ix особисту відповідь на історичну катастрофу й декларацію своєї громадянської і людської позиції щодо проблеми мілітаризму. Хоча всі ці твори подібні за своїм призначенням (як меморіальні), за географічними, національно-культурними та часовими показниками, вони дуже різноманітні в стильовому та композиційному відношенні, що говорить про важливість індивідуально-авторського аспекту жанрової традиції. Він $є$ вкрай показовим для побутування реквієму в середовищі професійної авторської музичної творчості, «оскільки індивідуальна композиторська інтерпретація жанрової традиції заупокійної меси в кожному окремому випадку привносить щось нове в ііі еволюцію. Особливе значення в цьому сенсі належить композиторам XX століття і сучасності, які не обмежені магістральними стильовими і жанровими нормативами, властивими попереднім епохам музичного мистецтва» (Кучурівський, 2019: 185).

Англійське музичне Відродження являє собою, на думку британського дослідника М. Тренда, «насіннєве ложе для англійського Реквієму» (Trend, 1985: 189), що забезпечило світоглядний імпульс його розвитку в національній музичній культурі, який прагнув створити «ідеальне минуле» 3 його свободою від чужих, поза англійських впливів (у тому числі свободи від римокатолицького канону заупокійної меси). Для композиторів «зближення» воєнних подій із ідеями Відродження було особливо важливим моментом задля утвердження англійської мови в музичному мистецтві як тієї, що репрезентує національну культурну свідомість у висловлюванні жалоби, що знайшло особливу актуальність у жанрі заупокійної меси. Однак англійський реквієм не завжди використовує латинський текст реквієму, але він завжди включає текст англійською мовою. Зазвичай ці твори прагнуть до більш цілеспрямованого, персонального вибору тексту, іноді в поєднанні 3 латиною, щоб висловити жалобу в звичній формі.

Реквієми Ф. Деліуса та Дж. Фоулда є грандіозними творами для великого хору та оркестру, які втілили композиторське розуміння Життя i Смерті, Добра і Зла, Небесного й Земного. Жанр реквієму став для них тією художньою формою, яка «... у ритуально-обрядовій формі стала втіленням християнського уявлення про смерть як перехід від Тимчасового страху, скорботи, каяття, тривоги до Спокою, Світла, Надії на Спасіння як справжніх цілей духовного життя християнина» (Кучурівський, 2019: 184).

У загально-стильовому відношенні Реквієм Ф. Деліуса не відображає естетики його сучасників, його музика більш тісно пов'язана 3 французьким імпресіонізмом. У французькій газеті 1908 року музика Ф. Деліуса описується не просто як імпресіонізм, а як продовження того, 3 чого почав К. Дебюссі: «Тим, чим Вагнер був для Вебера, Фредерік Деліус - для Клода Дебюссі. Повніший, більше органічний, сильніший, він одночасно тонкий і чутливий до нюансів. Як i попередник, він виглядає одягненим у веселку; нас постійно огортають делікатно відтінені акорди...» (Hughes, Stradling, 2001: 216). Така висока оцінка $\epsilon$ вражаючою для будь-кого, але це особливо дивовижно для англійського композитора. Можливо 3 цієї причини його музика була популярна більше на континенті, ніж в Англії. Спочатку його музика в Англії сприймалася неоднозначно, відгуки досить негативно описували іiі як «химерну та какофонічну», «невідповідну моїм вухам, сувору, непрохану та негарну». Але за підтримки його друга, диригента Т. Бічама (1879-1961), музика Ф. Деліуса врешті-решт здобула визнання в Англії.

Реквієм Ф. Деліуса - масштабний твір для змішаного хору, солістів сопрано та баритону, а також великого оркестру в п’яти частинах. Зви- 
чайне виконання триває приблизно тридцять хвилин. Нині лібрето приписують німецькому письменнику й музиканту Г. Сімону (1880-1941), але протягом багатьох років це було невідомо, тому приписувалось самому композитору. Існують суперечливі думки про фактичне джерело тексту, але більшість сходяться на думці, що він базується на філософії Фрідріха Ніцше. Подібним чином здається, що пісня кохання в партії баритону є посиланням до Пісень Соломона, хоча насправді їх композитор не цитує. Хоча текст був створений німецькою мовою, він перекладений англійською для прем'єри. Твір написаний між 1914 і 1916 роками, але прем'єра відбулася лише в 1922 році, й після цього він не виконувалася до $1960-x$ років.

Дослідники творчості Ф. Деліуса говорять про несвоєчасність його музичного вигляду, що наводить на думку про дивний психологічний стан його автора. М. Тренд пише 3 цього приводу: «Нібито плач за молоддю всіх націй, що впали та все ще падають у найбільшій європейській війні, - це насправді ще й полемічний напад на християнське вчення i загальноприйнятий християнський спосіб життя. Те, що Фредерік не був християнином, загальновідомо. Не може бути серйозно зараховано проти нього те, що він не зміг поділитися переконаннями, відкинутими більшістю жителів цієї планети. Але в перші дні війни в Англії з'явилося на деякий час сильне відродження релігійних емоцій, значною мірою навіяних переконанням, що битва відбувалася між двома сторонами, одна 3 яких підтримувала певні принципи вищої цінності, інша - ганебно кинула їх» (Trend, 1985: 195). Дійсно, текстова основа Реквієму є суто негативною за своїм змістом і здається прямим запереченням духу, властивому всій іншій музиці Деліуса, живому духу оптимізму, який знайшов своє відображення в творі із симптоматичною назвою - у «Месі Життя». 3 такою ж догматичною самовпевненістю, як найфанатичніший християнин, анонімний лібретист Реквієму заперечує безсмертя душі й виживання людської свідомості так, ніби щось аморальне $\epsilon$ в самій такій можливості. Результатом стає сумне не філософське та непослідовне поєднання суперечливих ідей; i, як часто буває, ця «раціоналістична» пропаганда переважно складається з цитат із Біблії. Проте музика цього твору відрізняється гармонійністю й мелодійністю, красою, рельєфом хорової фактури та драматургії. Крім того, сам композитор дуже високо оцінював свій твір: «Я не думаю, що я колись робив щось краще, ніж це» (Kovalenko, 1971: 74).
Для авторської концепції Ф. Деліуса визначальними стають принципи синтезу й об'єднання різних релігій у «справі миру» та протистояння війні; він прагне поєднати в своєму творі чотири основні релігії у музиці: християнську, ісламську, іудейську й буддистську, йдучи шляхом музичної символізації ідеї марності релігійно-ритуальних висловлювань про власне уявлення Бога в умовах світової трагедії. Так, у другій частині Реквієму протиставляються християнська «Алілуя» та мусульманське «Ла ил аллах» («Hallelujah» and «La il Allah»), що виступає музичним символом Вавилонської вежі як тотального непорозуміння. Цей намір стає ще зрозумілішим, коли соліст баритон перериває цей поліхоральний плач текстом про «земні магістралі ... повні криків, земні шляхи належать богам та ідолам». Далі йдеться про те, що, хоча люди знають про настання смерті, але коли вона настає, «ми втрачаємо знання всього». В заключних частинах текст також посилається на душу, сходить на вершину гори та приєднується до природи, що надає нехристиянські мотиви твору композитора.

У цьому контексті слід розглядати й відсутність воєнної образності в Реквіємі, крім посвяти («На згадку про всіх молодих Художників, що загинули на війні»): єдине посилання на війну (або загиблих у війні) в лібрето - це декларація сопрано на початку четвертої частини: «Я шаную того, хто вміє любити життя, проте без побоювання може померти. Він досяг вершин і завоював вінець життя». Відомо, що вже після того, як Ф. Деліус написав Реквієм, його племінник загинув на війні, i не виключено, що посвята була додана в цей момент. Однак зрозуміло, що з самого початку він задумував твір як відповідь війні, бо його завершення та прем'єра пов'язані з Війною.

У музичному плані хоровий твір англійського композитора відрізняється оригінальністю, оскільки його часто називають «квазіімпровізаційним», відзначаючи високе значення хроматичних гармоній, які мають багато спільного 3 вільністю атональної музики (Kovalenko, 1971: 82). Але відсутність тональних центрів компенсується інтонаційно-тематичними зв'язками між частинами циклу, в кожній із них можна знайти мотивні посилання на попередні. Реквієму притаманна дуже щільна хорова та оркестрова фактура, в кожній частині циклу використовується розділення окремих хорових партій, що надає значну фактурну мобільність великій конструкції твору.

Автор Реквієму миру Дж. Фоулд ніколи не здобував академічної музичної освіти, тому володів свободою творчої уяви і традиційних 
правил музичної композиції, що й визначило оригінальність його твору. Разом із своєю дружиною, скрипалем і співачкою М. МакКарті, Фоулд активно вивчав культуру й музику Індії, особливо теософію (саме етномузикологічні лекції дружини Дж. Фоулда ініціювали інтерес до Індії Г. Холста). Під час Світової війни обидва писали музику для військових: поки Фоулд робив це офіційно, МакКарті також писала патріотичні пісні для посилення бойового духу солдат. Вона сильно вплинула на задум Реквієму миру, співпрацюючи 3 ним і додаючи йому більше східного музичного впливу.

Реквієм Миру Дж. Фоулда суттєво відрізняється від Реквієму Ф. Деліуса. Тоді, як твір Ф. Деліуса вважався його найслабшою великою роботою та спочатку не був добре сприйнятим, Реквієм Дж. Фоулда вважається його найсильнішим і найважливішим великим твором. Останній був дуже добре сприйнятий спочатку, але користувався актуальністю та прихильністю лише тимчасово. Дж. Фоулд створив цей твір між 1919 та 1921 роками, він часто виконувався як музична пам'ятка Війни в перші роки після перемир'я. Вперше твір був виконаний у Ройял Альберт Холі в День Перемір'я (11 листопада) 1923 року та виконувався надалі в цю дату аж до 1926 року.

Незважаючи на очевидну популярність, сприйняття твору критикою було неоднозначним: «Успіх немає нічого спільного із музикою,

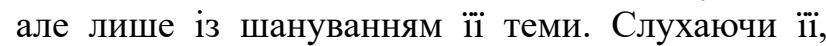
ми можемо легко уявити, що композитор був одержимий величчю функції, яку він виконував, настільки, що він був готовий - занадто готовий прийняти всі музичні ідеї, що виникали в нього. ... для нас це було так, ніби проповідник взяв якийсь простий текст, такий, як «Вклонімося Богу», та не зміг вийти за його межі» (Hughes, Stradling, 2001: 249). Твір не виконувався більше вісімдесяти років після 1926 року, а коли це сталося, відгуки критиків були теж досить прохолодними.

Частково труднощі зі сприйняттям цього твору полягають у його лібрето: у скомпільованому Дж. Фоулдом i M. МакКарті тексті використано перефразоване Писання, текст англійського письменника й баптистського проповідника XVII століття Джона Баньяна та поезія Кабіра, індуїстського письменника XVXVI століть. Це уникає єдиної релігійної традиції, а ідея пам'яті всіх жертв Світової Війни не класифікується як патріотична. Крім того, назви двадцяти частин (по десять у двох великих розділах) подано латиною, незважаючи на те, що весь текст написаний англійською мовою, крім
«Requiem aeternam», за яким слідує «Grant them rest eternal» (англійський переклад фрагменту католицької заупокійної меси). Музикознавці називають це «претензійним» (Trend, 1985: 186), хоча в інших англійських Реквіємах до творчого досвіду Дж. Фоулда також використовувалися латинські назви для частин. Однією 3 найбільш зауважених частин тексту є п'ятий розділ Audite, в якому соліст баритон закликає до миру між різними народами світу. Він закликає на північ, південь, схід і захід, називаючи групи людей у кожному напрямку (наприклад, «Ви, жителі Півночі - Ви, Гренландія, Камчатка, Лапландія ... Нехай мир Божий спочиває у ваших серцях»).

Виконавські сили, необхідні для втілення задуму цього твору, величезні. Як і в Реквіємі Г. Берліоза, композитор визначає кількість співаків та музикантів для кожної партії: сопрано, контральто, тенор і баритон є солістами в кількості близько восьми хлопців та восьми юнаків (яких можуть замінити жінки) та тенорів відповідно, принаймні сто сопрано, сто контральто, вісімдесят тенорів і вісімдесят басів, а також оркестр щонайменше 3 дев'яноста музикантів, включаючи дві арфи й орган. Окрім того, вимоги до ударних інструментів включають 3 Kettledrums, бас-барабан, цимбали, трикутник, гонг, трубчасті дзвони, великий дзвін і челеста. Прем'єра та наступні вистави у 20 -х роках включали понад 1200 виконавців. Незважаючи на ці численні сили, композитор також зазначає в партитурі, що доступною є стисла версія оркестрової партитури, що уможливлює виконання 3 невеликим оркестром - органом. Пізніше Дж. Фоулд також писав, що його можна навіть виконати хором із двадцяти чоловік з акомпанементом органу.

Реквієм миру відображає експериментальну ідею творчості Дж. Фоулда, яка так відрізняє композитора від своїх сучасників. Це виражається через такі прийоми, як: використання чвертьтонів, так званого «контрапункт тембрів» (оркестрову техніку, яка включає акорди, що поступово змінюються через тимбральні зрушення), пандіатонічний хроматизм і принцип повторності, який пізніше складатиме основу композиційної техніки мінімалізму. Мова йде про значне розширення композиторських уявлень про виразні можливості канонічного жанру, які вони створювали в рамках відродження національної традиції.

Висновки. Отже, в Реквіємах Ф. Деліуса i Дж. Фоулда виявляється тенденція до трансформації вихідної меморіально-заступницької функції богослужбового жанру в ідею загальноcmi (незалежно від конфесійної приналежності), 
загальної пам'яті про всіх, хто загинув у світовій війні. Саме такий зміст виявляється у творах англійських композиторів, які започаткували цілу низку оригінальних інтерпретацій жанрової традиції заупокійної меси представниками композиторської школи Великобританії у другій половині XX століття (Б. Бріттен, К. Дженкіс, Дж. Тавенер та інші). Цей ідейний зміст хорових реквіємів англійських композиторів вплинув на трансформацію образно-семантичного інваріанта заупокійної меси: мова йде про принципове розширення змістовно-смислових меж «меси мертвих», у котрій композитори об'єднують культурні традиції Заходу та Сходу за допомогою використання синтезу літературно-поетичних текстів - канонічних текстів латинського реквієму, мусульманської та індуїстської, релігійної і поетичної традицій. Тим самим образно-семантичний комплекс реквієму «переводиться» в більш об'єктивний план, пов'язаний $з$ музично-художнім втіленням універсальних категорій людського життя, актуальних для людського буття взагалі.

\section{СПИСОК ВИКОРИСТАНИХ ДЖЕРЕЛ}

1. Ковнацкая Л. Г. Английская музыка XX века (истоки и этапы развития): Очерки. М.: Советский композитор, 1986. $216 \mathrm{c}$

2. Кучурівський Ю. Жанрова традиція реквієму у творчості композиторів Великобританії останньої третини XX-початку XXI ст.: дис. ... канд. мист.: спец. 17.00 .03 - музичне мистецтво. Одеська національна музична академія ім. А. В. Нежданової. Одеса, 2019. 222 с.

3. Уилсон-Диксон Э. История христианской музыки [Пер. с англ.]. Мирт, 2001. 428 с.

4. Hughes M., Stradling R. The English Musical Renaissance, 1840-1940. 2nd edition. Manchester; New York: Manchester University Press, $2001.336 \mathrm{p}$.

5. Kovalenko S. The Twentieth-Century Requiem: An Emerging Concept. Ph.D diss. Washington University in St. Louis, 1971. $159 \mathrm{p}$.

6. Trend M. The Music Makers: Heirs and Rebels of the English Musical Renaissance, Edward Elgar to Benjamin Britten. London: Weidenfeld \& Nicolson, 1985. 288 p.

\section{REFERENCES}

1. Kovnatskaya, L. (1986). Anglijskaya muzyka XX veka (istoki i etapy razvitiya): Ocherki [English music of the twentieth century (sources and stages of development): Essays]. Moscow: Sovetskij kompozitor. 216 s. [in Russian].

2. Kuchurivskyi, Yu. (2019). Zhanrova tradytsiia rekviiemu u tvorchosti kompozytoriv Velykobrytanii ostannoi tretyny XX-pochatku XXI stolit [The genre tradition of the requiem in the works of British composers of the last third of the XX-beginning of the XXI century]: $\mathrm{PhD}$ of arts by specialty 17.00.03. Odessa: Odeska natsionalna muzychna akademiia im. A. V. Nezhdanovoi. 222 s. [in Ukrainian].

3. Wilson-Dickson, E. (2001). Istoriya hristianskoj muzyki [History of Christian Music]. St. Petersburg: Mirt. 428 s. [in Russian].

4. Hughes, M., Stradling, R. (2001). The English Musical Renaissance, 1840-1940. 2nd edition. Manchester; New York: Manchester University Press. 336 p. [in English].

5. Kovalenko, S. (1971). The Twentieth-Century Requiem: An Emerging Concept. Ph.D diss. Washington University in St. Louis. 159 p. [in English].

6. Trend, M. (1985). The Music Makers: Heirs and Rebels of the English Musical Renaissance, Edward Elgar to Benjamin Britten. London: Weidenfeld \& Nicolson. 288 p. [in English]. 